\title{
The Role of Women Entrepreneurs in Establishing a Sustainable Development in Sri Lanka
}

\author{
Kalpana R. Ambepitiya \\ Department of Management and Finance, \\ General Sir John KotelawalaDefence University, \\ Kandawala Estate, Rathmalana, Sri Lanka. \\ Kalpana.ambepitiya@gmail.com
}

\begin{abstract}
Woman has become a significant role in the economic development of any country. They contribute and support the economy extensively in different ways of being employed in different sectors. There are many women running successful businesses and some of them are very successful with entrepreneurial skills. It is a known fact that now many successful and world's enormous enterprises are owned and run by women. Many of them are actual or potential owners of trademarks, service marks, trade name as well as of industrial designs, patents and copyright. In developing countries some women are running small enterprises and many cooperatives that are proving so successful. Women entrepreneurs in both developed and developing countries are,
\end{abstract}


socially powerful in education and making a positive impact to the society. It is important to study how women in business and their skills can be utilized in order to achieve a sustainable economy for Sri Lanka. The objectives of this study have scattered in the study of women entrepreneurs to a sustainable economy, social system, and ecology. A descriptive research methodology is used for this study and administered to a selected sample from a specific population included with women in businesses and executives who are from private and public sector offices. The study consists of six month duration which uses a questionnaire as the survey instrument. Using the survey, it has resulted significantly the women entrepreneurs can be positioned to play an important role in promoting sustainable practices in economics, social system and ecology, to result a sustainable development. The researcher concludes the study by observing the positive effect on the economy and the development, the Women entrepreneurship is a key to the developing world to promote sustainable practices in business.

Keywords; Entrepreneurship, Sustainable development, Women in business, Economy, Development 


\section{Introduction}

In the 1970s, women left home and entered the workforce in droves, women today is leaving the workforce in droves in favour of being at home. But unlike generations of women before, these women are opting to work in the home not as homemakers, but as job-making entrepreneurs. Many women start businesses that align with personal values and offers freedom and flexibility when it comes to things like scheduling. The glass ceiling that once limited a woman's career path has paved a new road towards business ownership, where women can utilize their sharp business acumen while building strong family ties (Forbs 2012). The development of women is an integrated and unified concept, stretching across economic, social and cultural fields (Mehta and Sethi 1997). Women participation has been considered as a significant factor in economic and social development. However, they are reasonably unexploited as a source of Entrepreneurship in both developing and developed countries. This is a true fact principally in areas of new business creations (Brush 1994).

In the last few decades, the attitudes of people have been changed and women entrepreneurs are considered as significant in economic development and wealth creation. Women entrepreneurs also recognized as social icons to motivate women in developing countries. Women se significant number of the businesses and their productive 
activities, particularly in the industry makes them a force to be reckoned with and empower them in the overall economic development of their nations. Whether they are involved in small or medium scale production activities, or in the informal sectors, women's entrepreneurial activities are not only a means for economic survival, but also have positive social repercussions for the women themselves and their social environment (UNIDO 2001).

In the last couple of decades, there has been a change in attitude and entrepreneurs are considered to be important in relation to both wealth creation and economic regeneration. Indeed, the role and importance of female entrepreneurship and new business creation to both developed and developing economies have received increased attention from academics and policy makers in recent years. This growth in interest in the economic contribution of entrepreneurship has been reflected in an increased level and variety of public and private sector policy initiatives at local, regional and national levels to stimulate and support of the development of the sector (Henry et al 2003). In this case, women entrepreneurs were given many opportunities in starting new businesses and supports internationally. Female-run enterprises are steadily growing all over the world, contributing to household incomes and growth of national economies. However, women face time, human, physical, and social constraints that limit their ability to grow their businesses. Women's development is directly related to the nation's development. Therefore, sustainable 
development of women's resources, their abilities, interests, skills and other potentialities are of paramount importance needs of this sector. Women Entrepreneurship responds to increasing demands for best practices and tools to integrate gender in private sector development.

In view of the growing importance of entrepreneurship- oriented development assistance and in response to the fact that about $40 \%$ of enterprises in developing countries are owned and run by women (Zororo 2011). Observation and empirical evidence point to and reveal that the relationship between women entrepreneurship and the sustainable development. An entrepreneur offers some new value(s) to the society sometimes in the form of innovative or novel things through the creation of a firm. Women entrepreneurship is a potential means of empowering people, developing rural women and solving other social problems. Women entrepreneurs can be positioned to play an important role in promoting sustainable practices in economics, social system and ecology, to result a sustainable development.This research aims to study the role of women entrepreneurs in sustainable development by concerning the adaptations of social, economical and environmental practices in business operations. Followings are the sub objectives,

1. To examine the impact of the activities of women entrepreneurs on the economy of developing countries. 
2. To determine the effect(s) of activities of women entrepreneurs on the culture of their own.

3. To ascertain the impact of women entrepreneurs activities to protect the eco-system of developing countries.

\section{Literature Review}

Entrepreneurship is a dynamic process of vision, change, and creation. It requires an application of energy and passion towards the creation and implementation of new ideas and creative solutions. The essential ingredients include the willingness to take calculated risks in terms of time, equity, or career; the ability to formulate an effective venture team; the creative skill to marshal needed resources; the fundamental skill of building a solid business plan; and, finally, the vision to recognize opportunity where others see chaos, contradiction, and confusion. Many business entrepreneurs around the world have exploited the environment with impunity, without any thought of sustainability. Entrepreneurs seek growth and profits within the business world. They are constant innovators and always are trying to capture larger market shares in the competitive marketplace. They are pioneering individualists who create one venture after another and one innovation after another (Frederick and Kuratko 2010).

As Birley \& Harris (1988) say to analyze the factors which influence the initial entrepreneurial decision is used to develop a theory for 
female entrepreneurs. The model describes three broad groups: (a. "Antecedent Influences" include those aspects of the entrepreneurs' background which affect her motivations, perceptions, and skills and knowledge. They include genetic factors, family influences, education, and previous career experiences. (b.The "Incubator Organization" describes the nature of the organization for which the entrepreneur worked immediately prior to start-up. Relevant factors include the specific geographic location, the type of the skills and knowledge acquired the degree of contact with possible fellow founders, and the extent to which the entrepreneur gains experience of a small business setting. Beyond these, there are the particular motivations and triggers to stay with or to leave the organization - the push versus pull factors. (c."Environmental Factors" external to the individual and to her incubator organizations provide an important setting within which the individual entrepreneur is able to flourish. Important factors here include the general prevailing economic conditions, but more specifically the accessibility and availability of venture capital, role models of successful entrepreneurs, and the availability of supporting services.

According to the classical definition given by the United Nations World Commission on Environment and Development in 1987, development is sustainable if it "meets the needs of the present without compromising the ability of future generations to meet their own needs." It is usually understood that this "intergenerational" 
equity would be impossible to achieve in the absence of present-day social equity, if the economic activities of some groups of people continue to jeopardize the well-being of people belonging to other groups or living in other parts of the world.

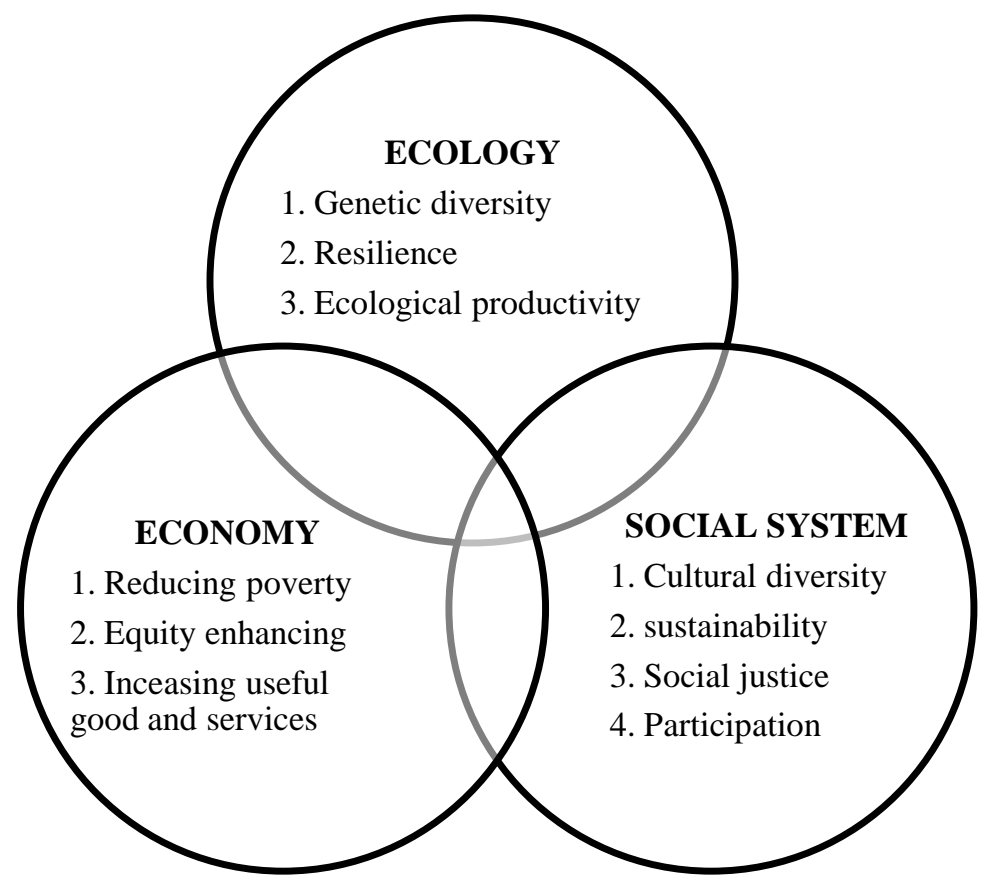

\section{Figure 1 Objectives of sustainable development}

Source: Beyond Economic Growth: An Introduction to Sustainable Development

Whilst many of the early contributions to defining sustainable development came from the disciplines of economics and ecology, it is the third sphere that has accommodated much recent work. For Starkey and Walford (2001), for example, sustainable development is 
a moral concept that seeks to define a 'fair and just' development. They suggest that since the environment is the basis of all economic activity and of life itself, 'it is surely only right that the quality and integrity of the environment be maintained for future generations' Notions of 'environmental justice' are now a prominent part of contemporary discussions of the meaning and practice of sustainable development and take the moral concerns further: in addition to environmental protection, the concern is for how environmental hazards (such as pollution) and goods (such as access to green space) are distributed across society. Environmental justice also encompasses a concern for the equity of environmental management interventions and the nature of public involvement in decision-making. Understanding is mounting of the political nature of sustainable development in practice; how the solutions proposed and the choices and trade-offs made can carry different costs for different groups of people.

Women own nearly 8 million businesses in the United States accounting for \$ 1.2 trillion of GDP. Women tend to spend more of their earned income than men on the health and education of their families. In the United States, women went from holding 37\% of all jobs to nearly $48 \%$ over the past forty years. Some statistics showed that the reductions in barriers to female labour force participation would increase the size of GDP such as USA 9\%, Europe 13\% and Japan $16 \%$. The reduction in barriers to women's equal access to 
productive resources could raise total agricultural output in developing countries by $2.5 \%$ to $4 \%$. It will also result to reduce the number of hungry people in the world by up to 150 million people (The World Economic Forum Gender Gap Report and the Food of United Nations 2014).

\section{Conceptual Framework}

\section{Figure 2: Conceptual framework}

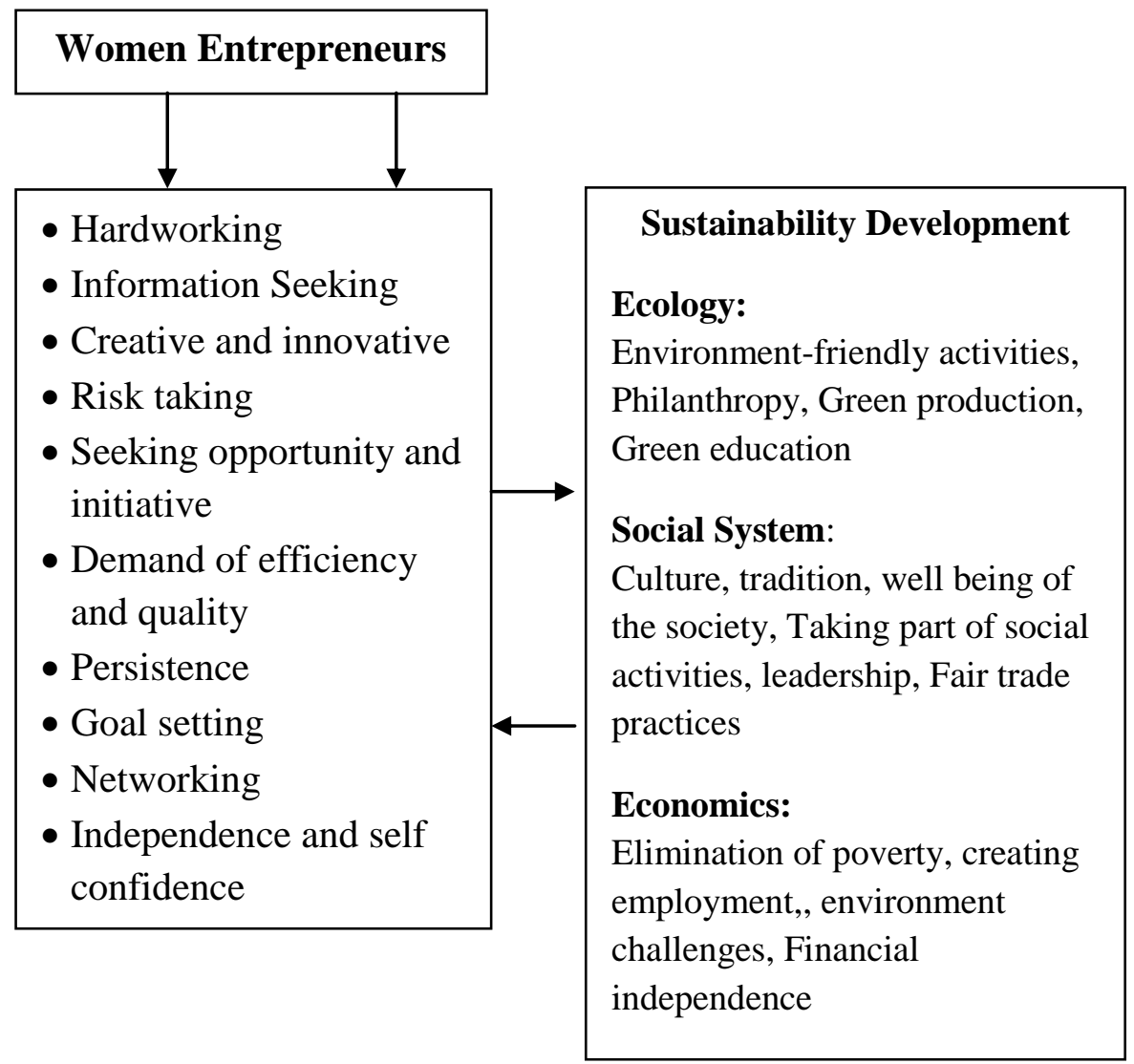

Source: Developed by the researcher 


\section{The Methodology and Model}

This study is to examine the role of women entrepreneurs in establishing a sustainable development in developing nations. Therefore, sixty (60) women entrepreneurs representing four developing countries and forty (40) executives of private and public sector companies were selected to conduct this study.

\section{Sample proportion}

Table 1: Sample Proportion

\begin{tabular}{|c|l|c|}
\hline Name of the sample & \multicolumn{1}{|c|}{ Proportion } & No. of participants \\
\hline Women entrepreneurs & $\begin{array}{l}\text { Sri Lanka - 30 } \\
\text { India - 15 } \\
\text { Maldives - 10 } \\
\text { Nigeria - 05 }\end{array}$ & 60 \\
\hline Executives & $\begin{array}{l}\text { Private sector - 25 } \\
\text { Public sector - 15 }\end{array}$ & 40 \\
\hline
\end{tabular}

Source: Developed by the researcher

An empirical survey was designed with two sets as to study the views and experiences of women entrepreneurs who are using Facebook, emails and google+ sites by using 'Snowball sampling' method since questionnaires were distributed among the above social media network communities and friends living in selected countries. Secondly, informal interviews were conducted with some women entrepreneurs in order to study the challenges, opportunities and practical applicability of women entrepreneurship. There were 60 women entrepreneurs and 40 executives participated in this study. The 
convenience sampling method was used in the second set to obtain more scientific result that could be used to represent the entire population. Therefore the sample was selected from the sampling frame which was given by selecting public and private sector organizations. Women entrepreneurship has the influence of controllable variables such as being a philanthropist and environmental friendliness, intention of eliminating poverty and support employment, intention to be financially independent, inborn talents and abilities and non controllable variables such as culture, tradition, economic growth and country's SME policy. Later, the above mentioned poverty elimination and employment development, becoming a philanthropist by practicing green activities in business operations have evaluated and the correlation was measured between the each of them. Research data analysis was conducted in the methods of univariate analysis, such as frequency tables, diagrams, correlation and measures of dispersion.

\section{The Findings}

This study obtained data from 100 participants with a questionnaire based survey. 20 of them participated in interviews to provide unstructured facts. 


\subsection{Women Entrepreneurs in Ecological Development}

The above data in Figure 3 demonstrated those women's entrepreneurs' engagement with environment-friendly activities in business operations. More than 50\% women entrepreneurs agreed that they run businesses with minimizing the bad effects to the environment. Many of them stated that disposal and waste management key areas they mainly concern and there is an extra income that they can generate by practicing waste management and proper disposal practices. The sample of executives gives more than $50 \%$ consensus to prove environment-friendly business activities of women entrepreneurs. According to them, women' inborn ability of neatness and carefulness are they significant reasons for this occurrence.

Figure 3: Environment-friendly activities in business operations

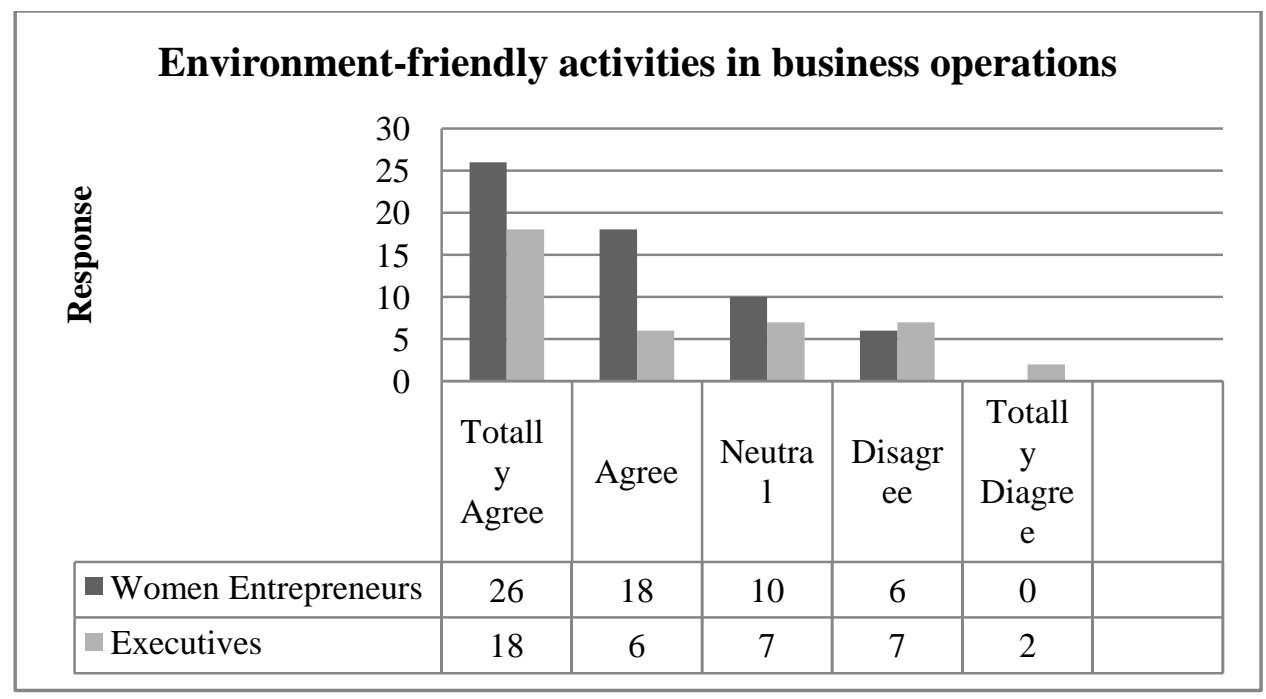

Source: Survey data 
Women entrepreneurs are well promoted green practices and applications in productions and services. It is clearly stated in the Figure 4, more than $50 \%$ of women entrepreneurs accept that they have been adopted green applications in production and services. And they promote green practices in marketing, advertising, staffing etc. The access to information have been made them to understand how important these things in business. Activities of Non-governmental organizations became prominent in creating awareness of green practices to emerging businesses. Sample of executives also agree upon the statement and proved that women entrepreneurs are green promoter in production and services. According the executives, this is a unique area that women in business developed which they can use to compete in the market place.

Figure 4: Application of green practices in production and services

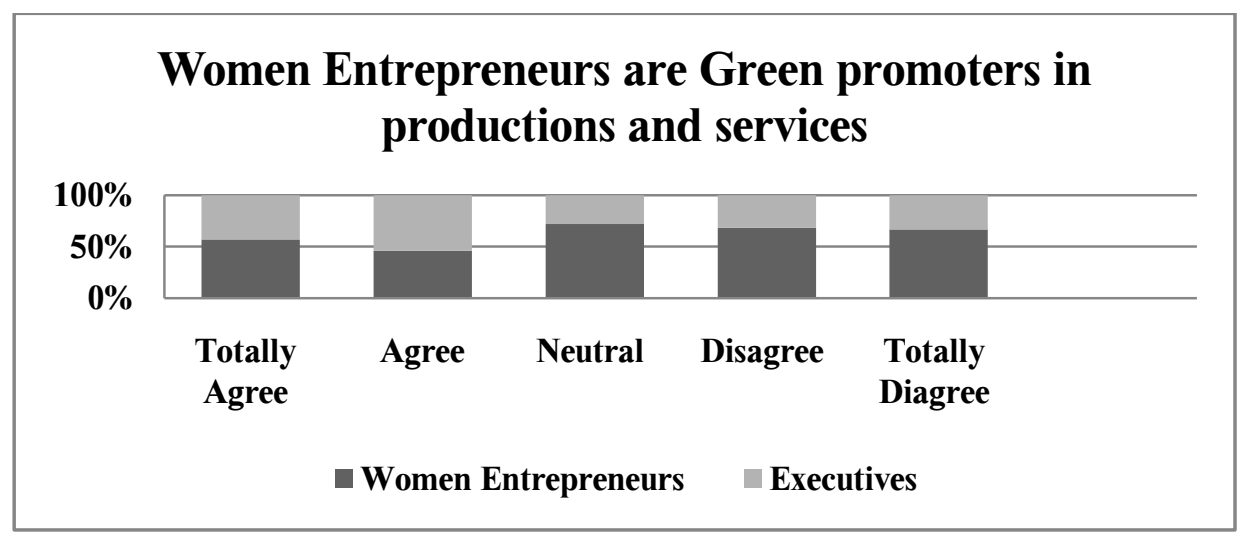

Source: Survey data 
The Figure 5 presents the correlation between environment-friendly practices in business activities and promoting green activities in production and services. There is a positive, strong partial correlation between these two variables. Therefore, women entrepreneurs who apply environment-friendly activities in business practices can be considered as green promoters.

Figure 5: Correlation between promoting green activities in production and services and taking environment-friendly practices in business activities

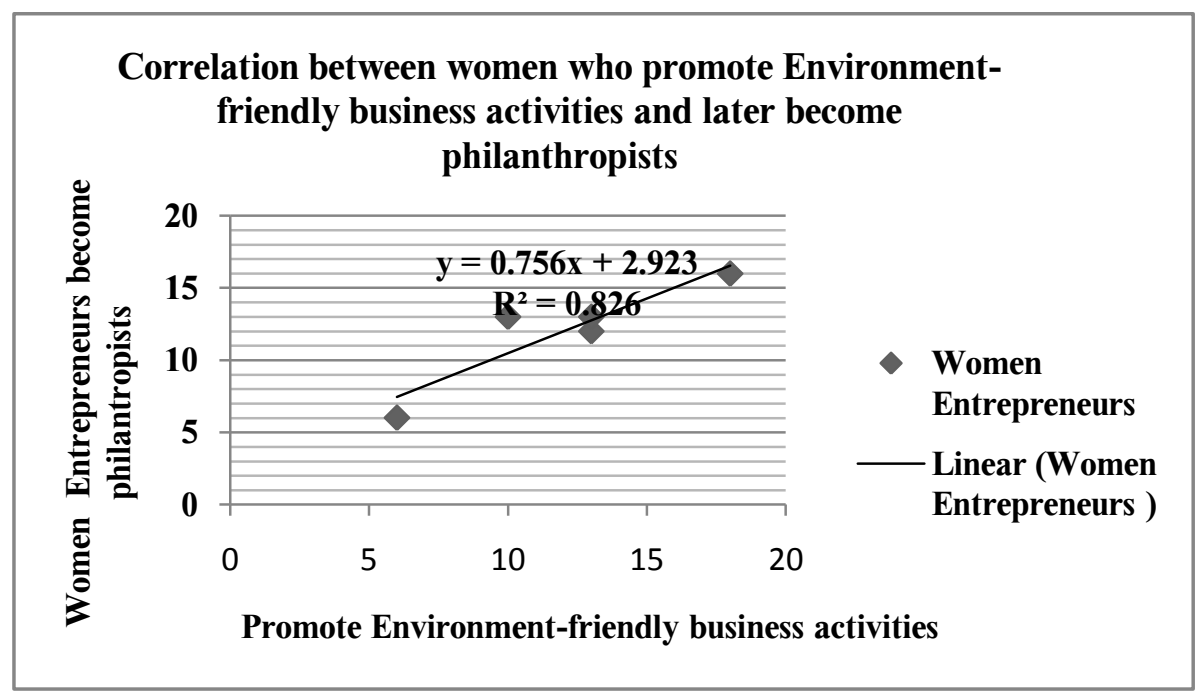

Source: Survey data 
Figure 6: Most women entrepreneurs become philanthropists

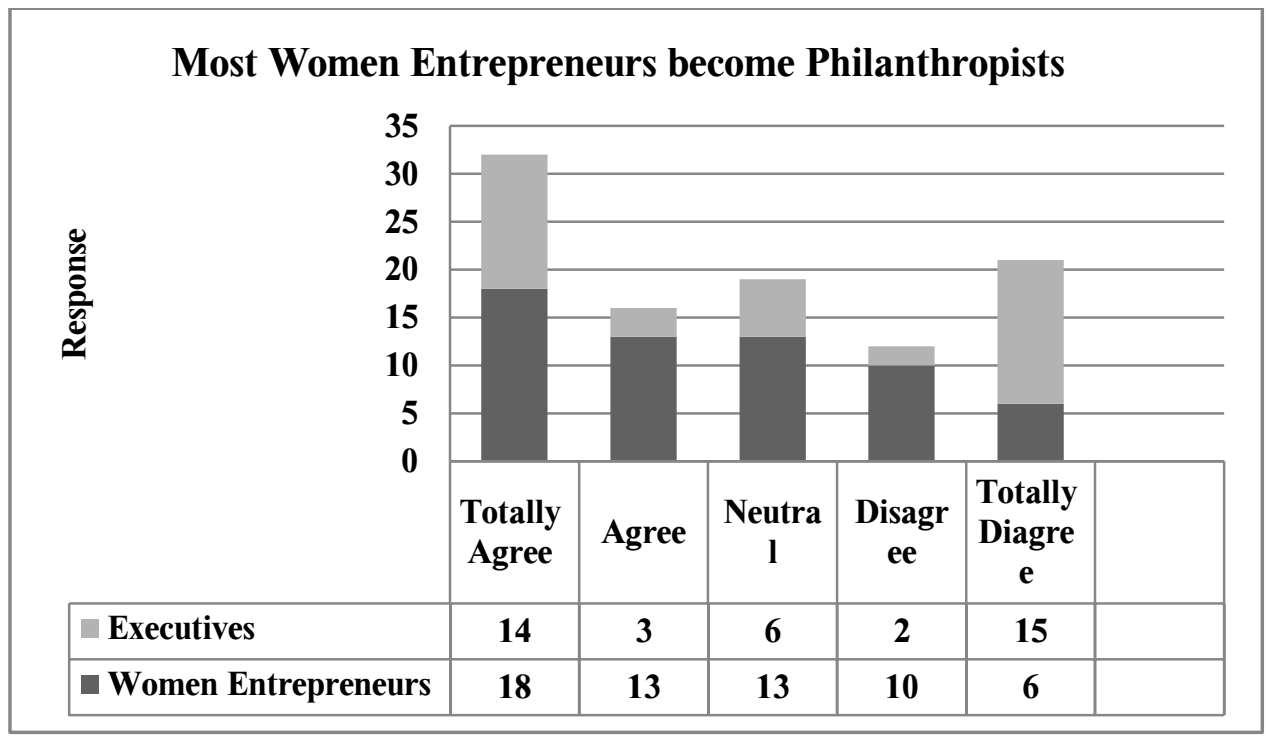

Source: Survey data

It is dispassionate to prove that most women entrepreneurs become philanthropists later to serve the society well according to the responses of executives. This is difficult to apply in developing countries. Some women continue their businesses while pay more attention to ecological and charitable activities. Some minor scenarios were found that women completely left or sold out the business to become a philanthropist. However the women entrepreneurs in this sample still believe that they can become philanthropists later and the results showed in the Figure 6 clearly. However, becoming a philanthropist is not an easy a task in a developing country. 
Figure 7: Best icons to promote Green education

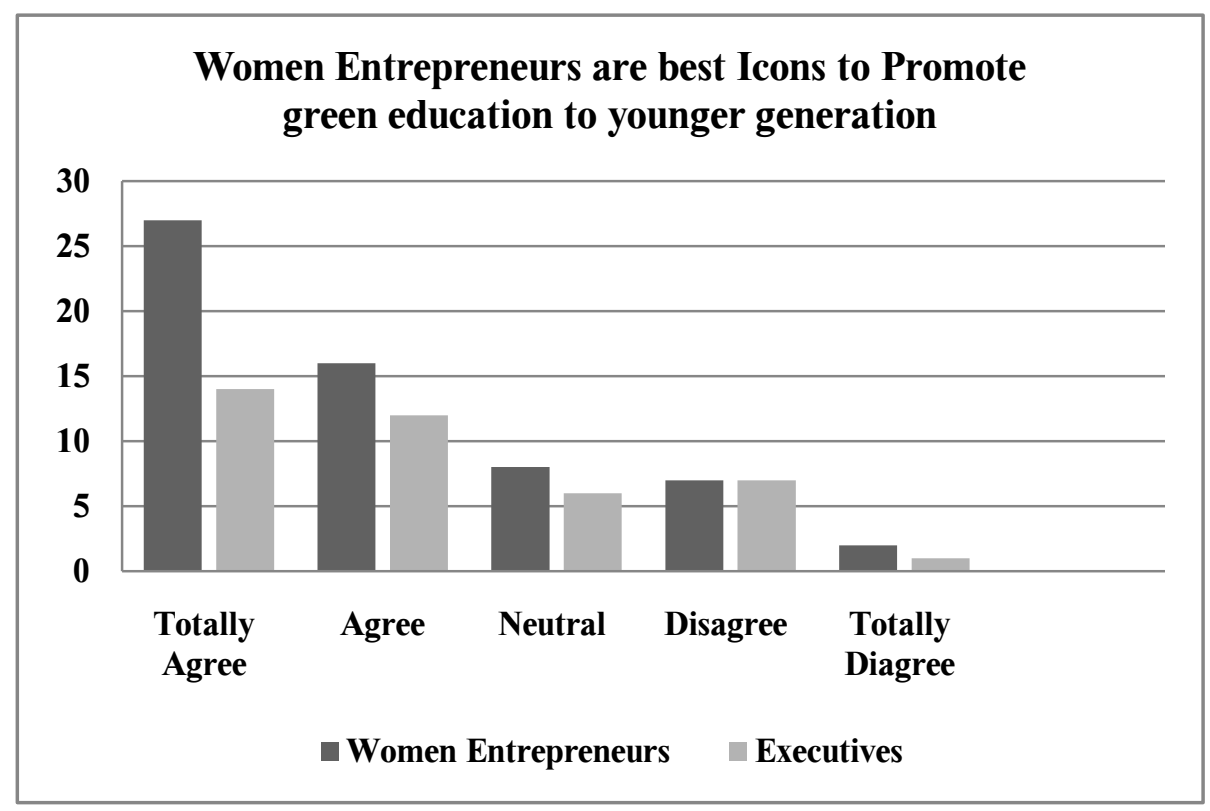

Source: Survey data

It is required that the young generation of a country should be aware and educated on best suitable business practices. Women entrepreneurs who have been adopting green activities into business practices and testing them on production and services also can take this job. According to the Figure 7, more than $60 \%$ of women entrepreneurs and more than $50 \%$ of executives agree upon the women entrepreneurs are suitable icons to educate the younger generation about good business practices. 
Kelaniya Journal of Human Resource Management

Volume 8 Number 2 July 2013

Figure 8; The correlation between becoming a philanthropist and being a social icon the educate the younger generation

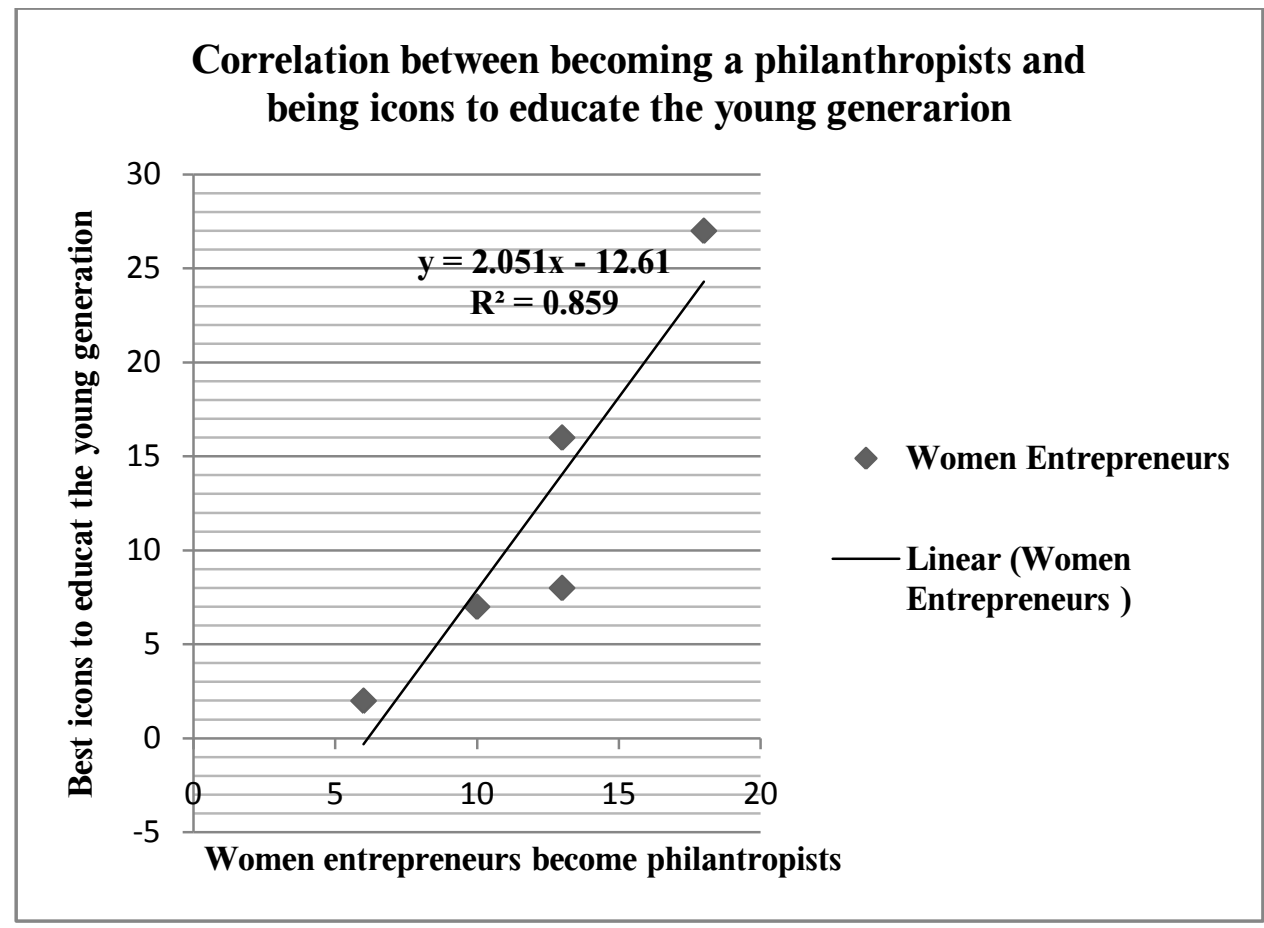

Source: Survey data

Figure 8 presents the relationship between becoming a philanthropist and being an icon to educate the younger generation of a country. There is a position strong positive partial relationship between them. Therefore, Women Entrepreneurs can be icons to educate the young will result them to become philanthropists in the future. 


\subsection{Women entrepreneurs in Economic development}

Figure 9: Women entrepreneurs support to eliminate the poverty

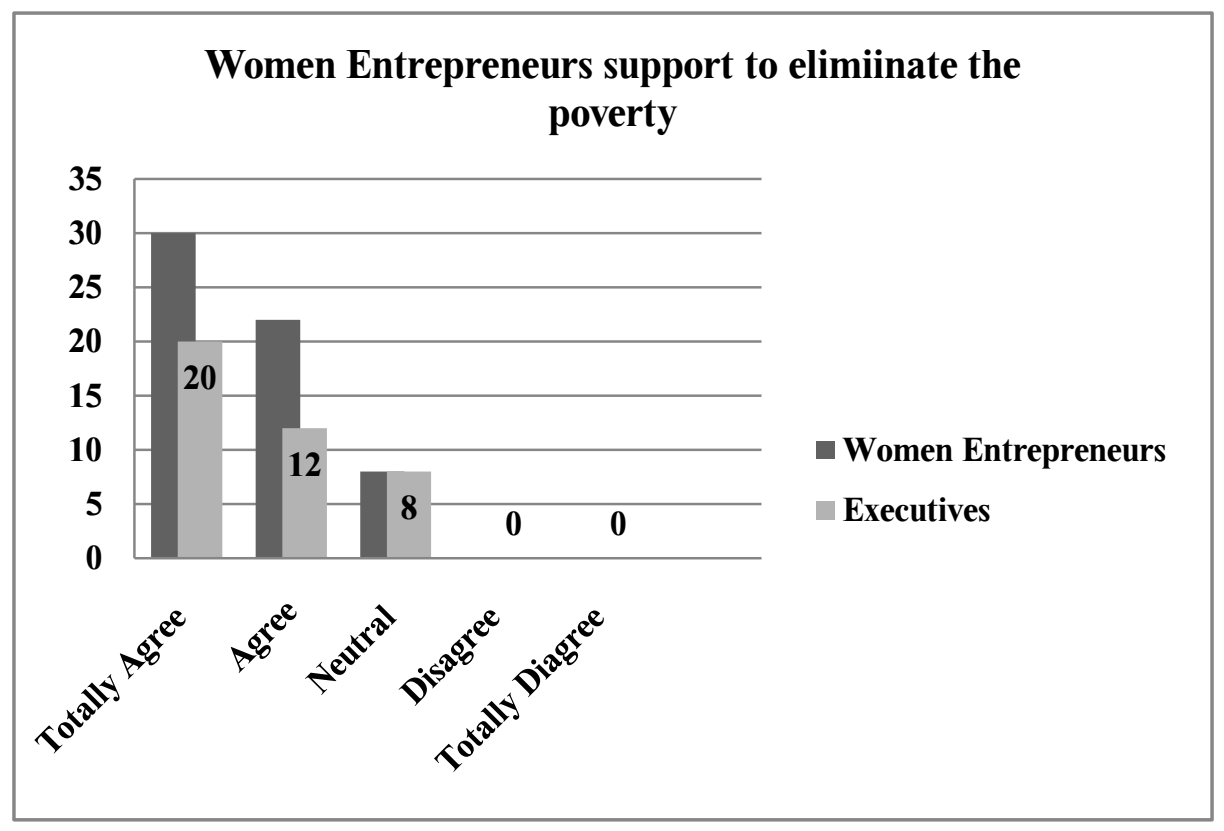

Source: Survey data

The majority of women entrepreneurs in the sample were agreed upon that they contribute to eliminate the poverty. They earn for themselves and the family, therefore the family can fulfil all the necessary requirements and in such families the burden of earning is not $100 \%$ responsibility of men. On the other hand, entrepreneurship helps women to use their abilities and skills in a maximum capacity, while obtaining the self satisfaction. As in the Figure 9, more that 50\% executives also agreed that women run businesses contribute to eliminate the poverty of a country. 
Figure 10: Women entrepreneurs provide employment opportunities to the society

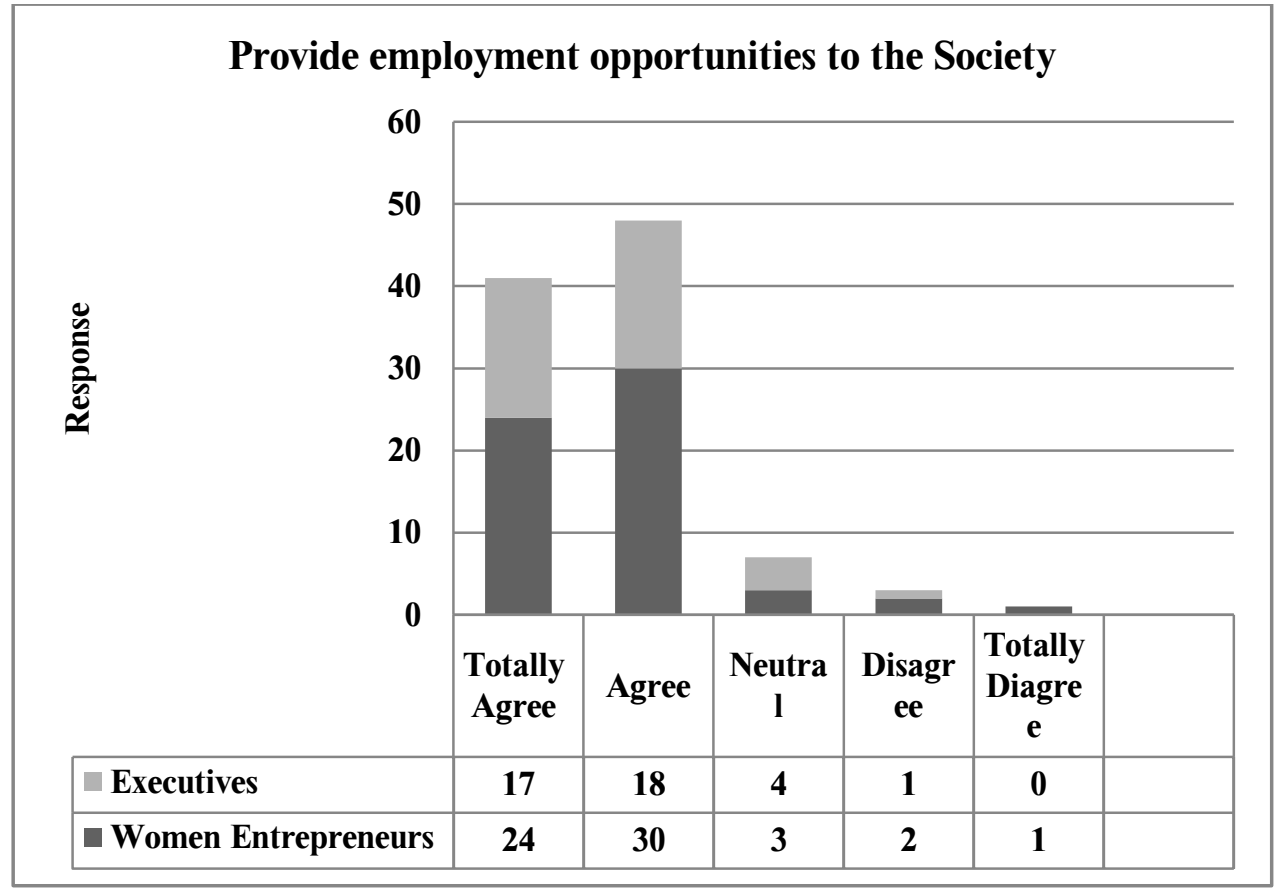

Source: Survey data

As shown in the Figure 10, providing employment opportunities is one important factor of why a developing nation wants more women entrepreneurs. However, women entrepreneurs in the sample and the executives of the participations stated that the majority of women is supporting society and the country's economy by offering goods and services and offering employment opportunities. Providing employment opportunity is helpful in eliminating the poverty. 
Figure 11: Correlation between eliminating poverty and providing employment opportunities

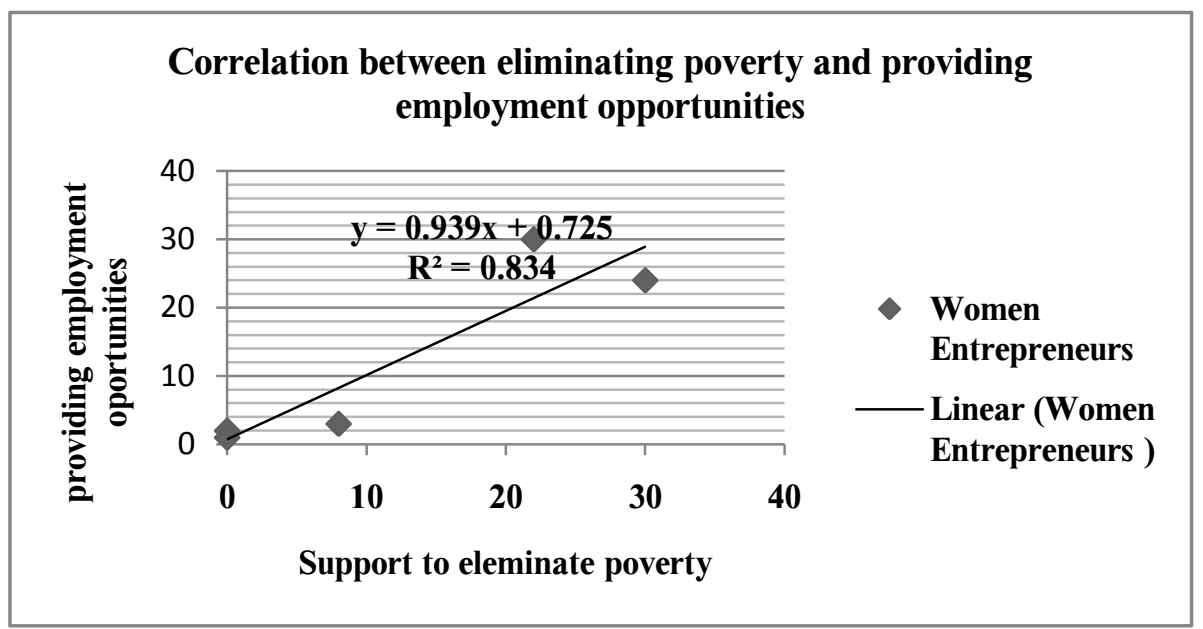

Source: Survey data

As Figure 11 presents, there is a positive partial, but strong relationship between women's entrepreneurs' activities to eliminate the poverty and the employment opportunities created by the actions of women entrepreneurs. This is significant, especially for a sustainability driven economy.

Women in businesses worldwide have created independent women. It is very common in developing countries in Africa, mainly women run businesses support them to feed their whole family. Social issues like, domestic violence, prostitution also can be eradicated if the women can become independent financially by running a business. According to the Figure 12, the majority of women entrepreneurs and executive in two samples agreed upon that the women entrepreneurs become financially independent. 
Kelaniya Journal of Human Resource Management

Volume 8 Number 2 July 2013

Figure 12: Women entrepreneurs are financially independent

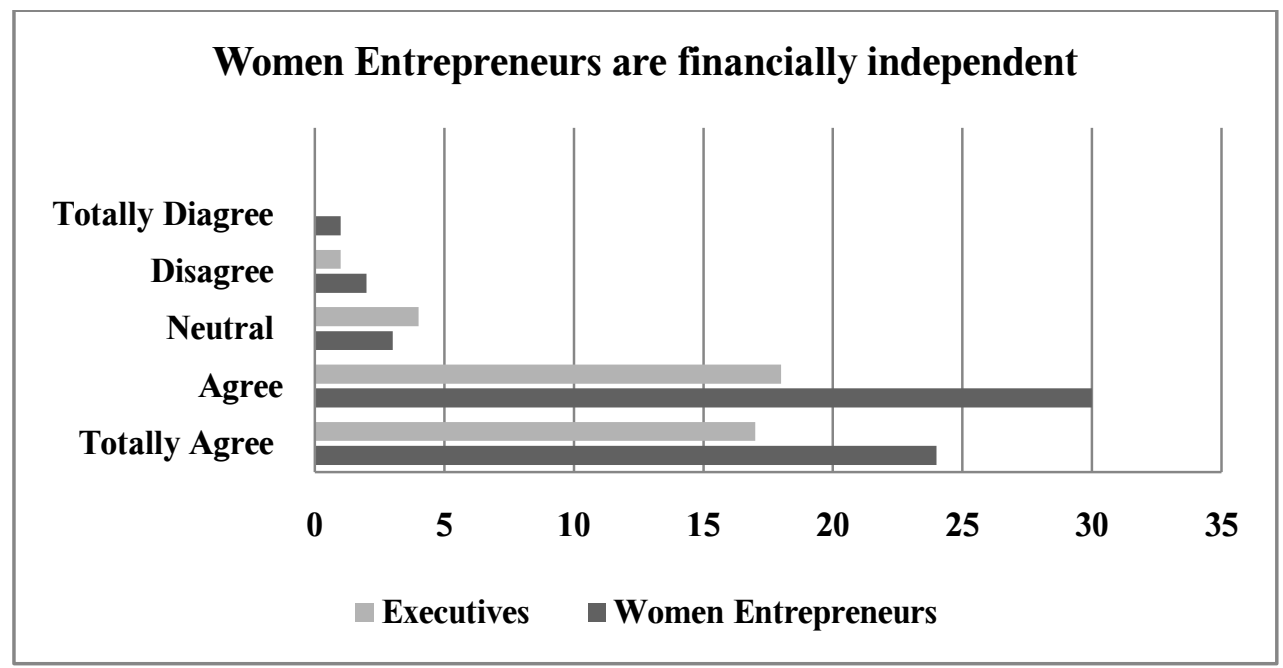

Source: Survey data

\subsection{Women Entrepreneurs in Social Development}

Figure 13: Women entrepreneurs are social examples of facing challenges

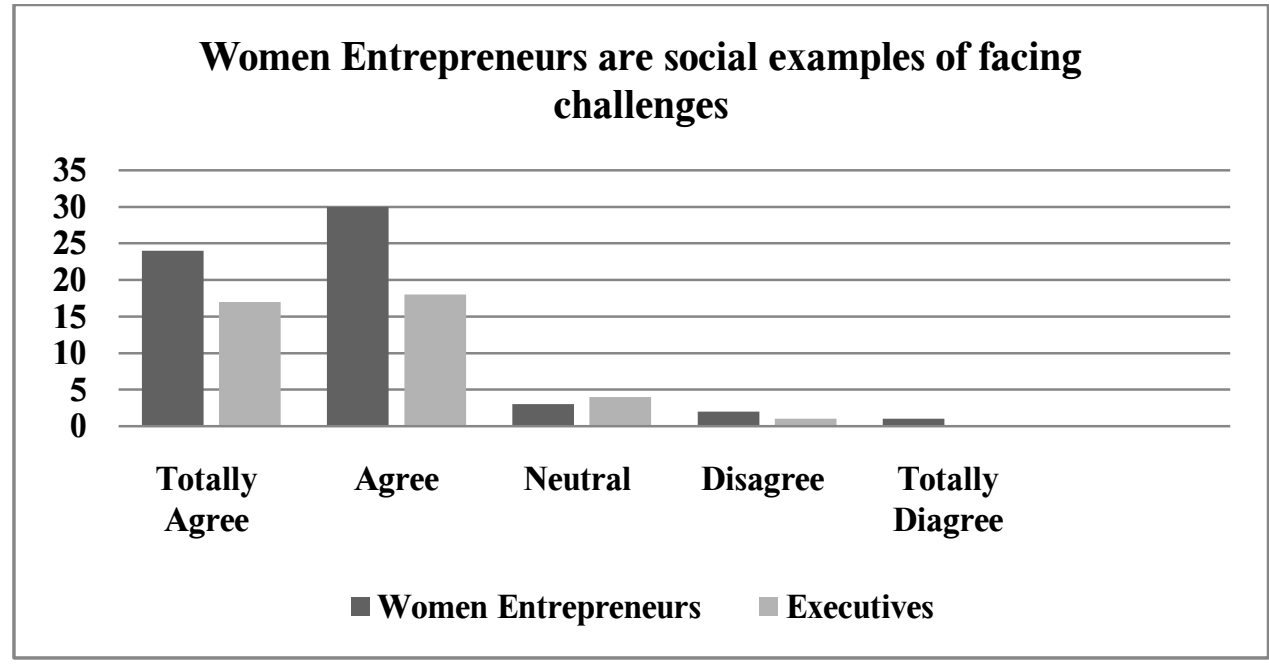

Source: Survey data 
It is a highly considerable thing in economic development is women and their employment. Women are the main character in the family who manage the well being of the family. Men earn and women mange it in order to fulfil the requirements of the family. Women receive many challenges in a developing country. It is not easy to manage and survive. It is significant that managing a business by paying the attention to the development of the family is challengeable. But women entrepreneurs have overcome it. At present in the Figure 13, the majority of women entrepreneurs and executives who participated in this survey have agreed upon those women entrepreneurs take and face challenges always coming from the external environment.

Figure 14: Women entrepreneurs provide useful goods and services to the society

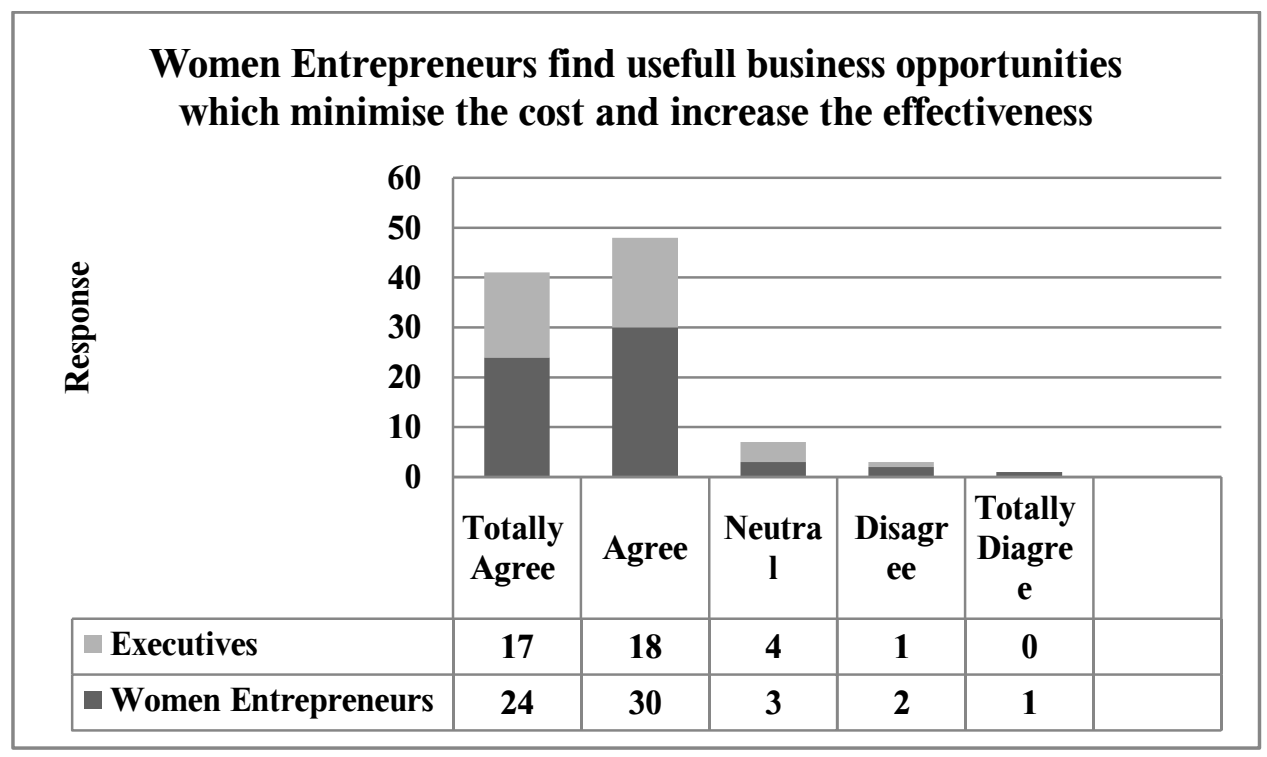

Source: Survey data 
Women entrepreneurs find useful business opportunities where make more profits in production of goods and services. Goods and services for day to day life of people are mostly available to women entrepreneurs. However the Figure 14 shows, more than $50 \%$ of women entrepreneurs accepted that they find business opportunities of necessary goods and services in the country. Mainly agriculture, clothing, beauty culture, food, etc. are few of main industries where women entrepreneurs run business operations. Sample of executives also averagely agreed on that those women entrepreneurs engage in useful goods and service businesses. According to them, it is necessary to have businesses which provide useful goods and services when the country establishing sustainable development.

According to the Figure 15, most women entrepreneurs and executives in two samples have agreed upon the women entrepreneurs promote culture and traditional aspects through business operations. Women always try to be inline their activities with cultural and traditional aspects. Women play a key role in practicing cultural aspects and tradition specifically in developing nations. Women entrepreneurs who have responded to this study exclusively mentioned that they apply and use traditional methods of productions, for example, indigenous agricultural methods to protect nutrition and freshness of vegetables. 
Figure 15: Women entrepreneurs promote culture and traditional aspects through business operations

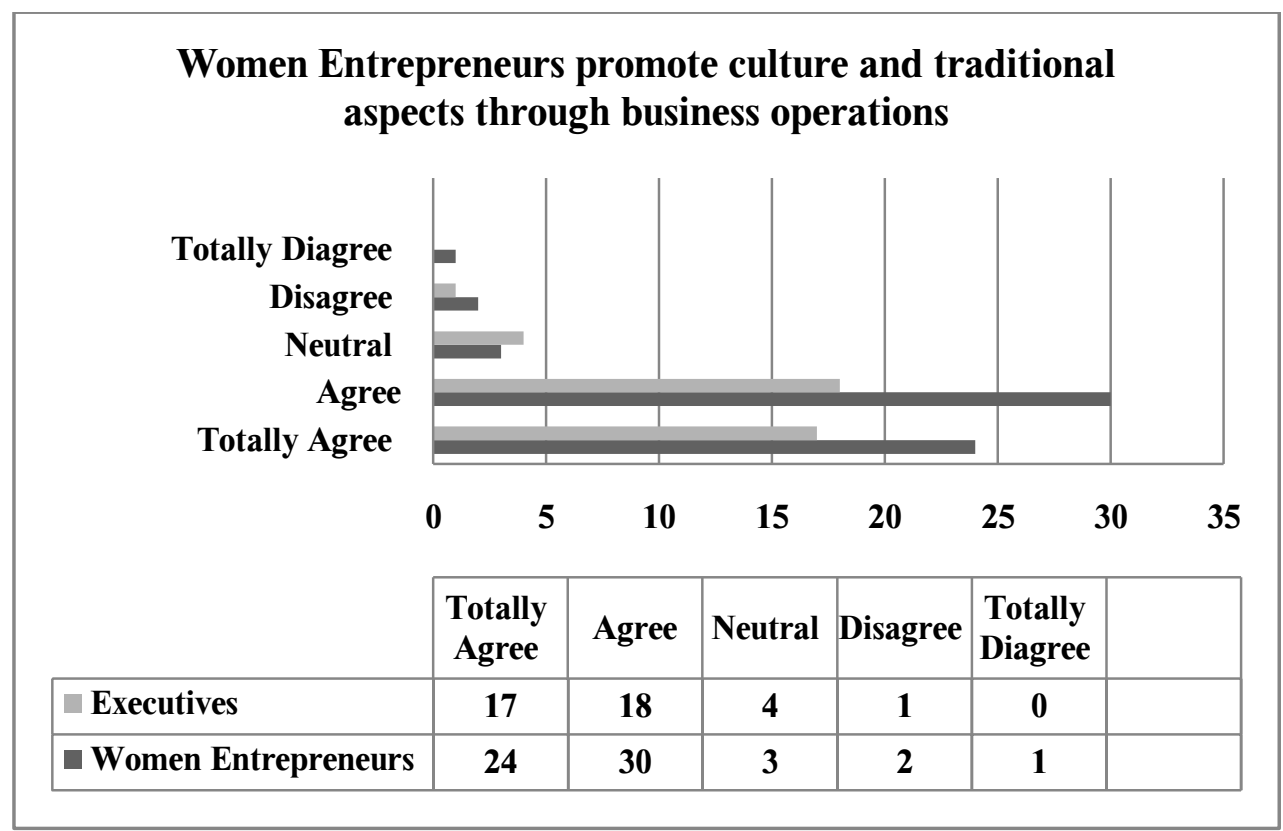

Source: Survey data

Figure 16: Women entrepreneurs, equally contribute to the well being of the society

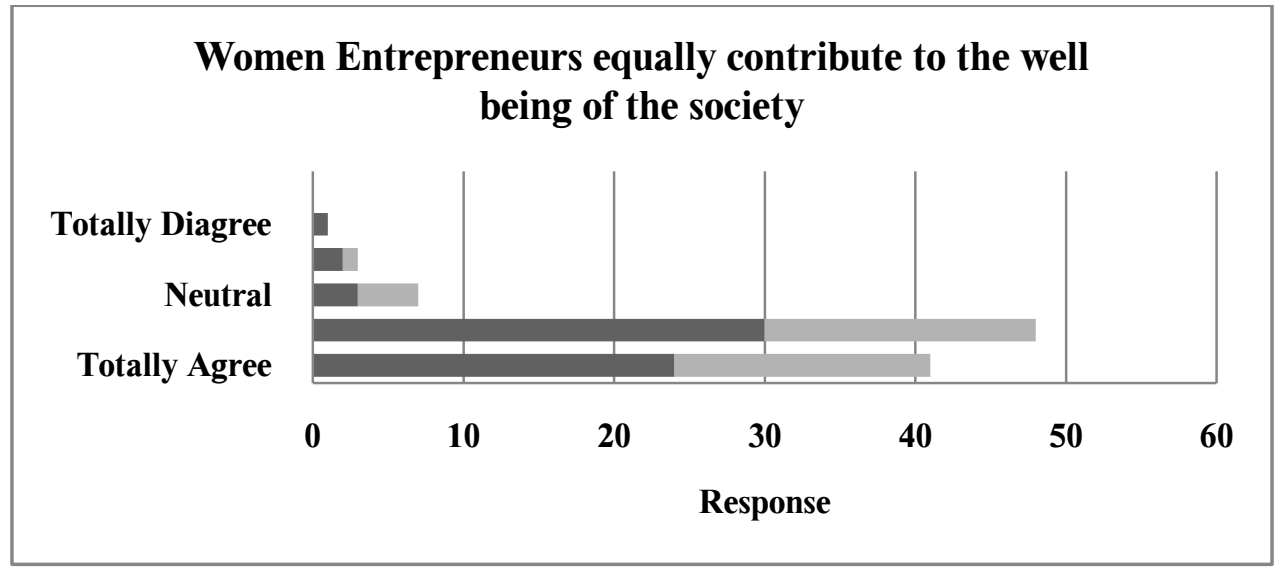

Source: Survey data 
Women contribute to the society by playing different roles like housewife, mother, daughter and a good citizen. The role and the responsibility of women entrepreneurs to the society are considerably high as presented by the Figure 16. Women entrepreneurs and executives both have agreed upon the women entrepreneurs contribute to the well being of the society equally like other entrepreneurs.

\section{Figure 17: Frequent participation in social activities and take leadership}

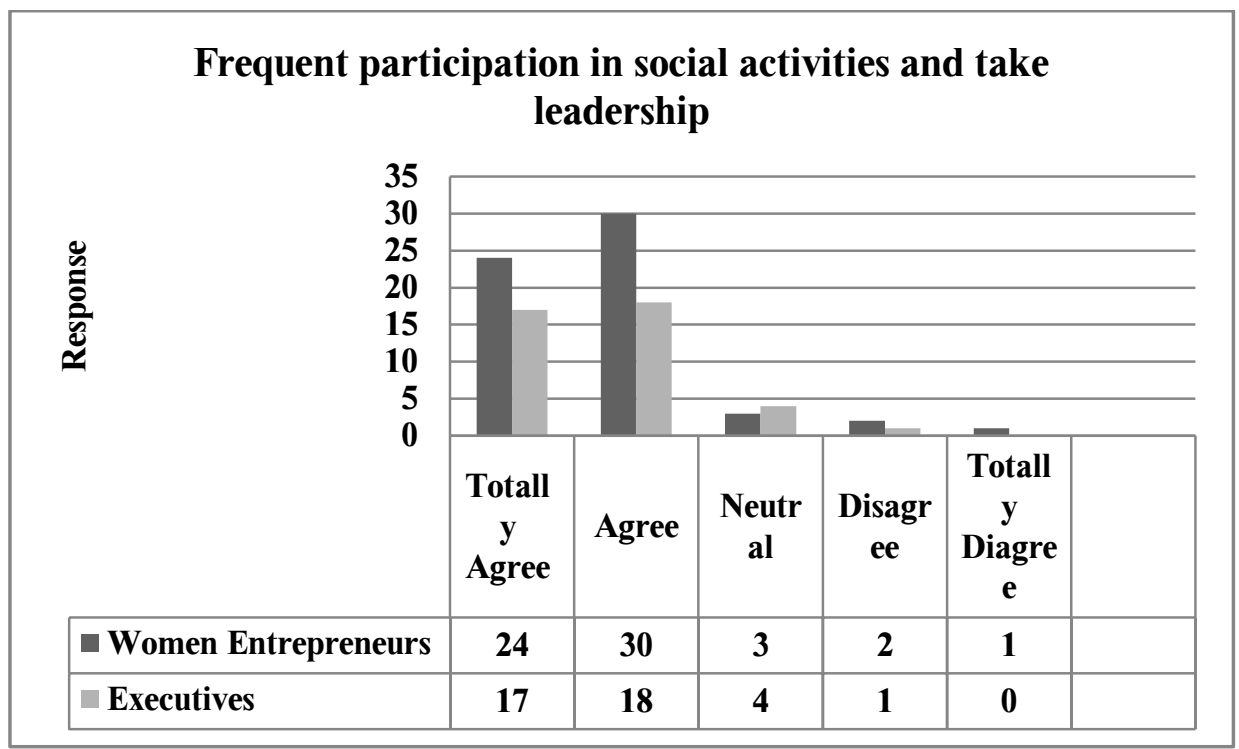

Source: Survey data

According to the Figure 17, two samples have agreed with more than $50 \%$ of the women entrepreneurs frequently participate in social activities and take leadership. Social gatherings, charity events, professional development occasions, unions, political party campaigns and events, etc. are the considered social and political activities where women participate and taking leadership roles. 
Figure 18: Women entrepreneurs practice and admire fair trade and fair business operations

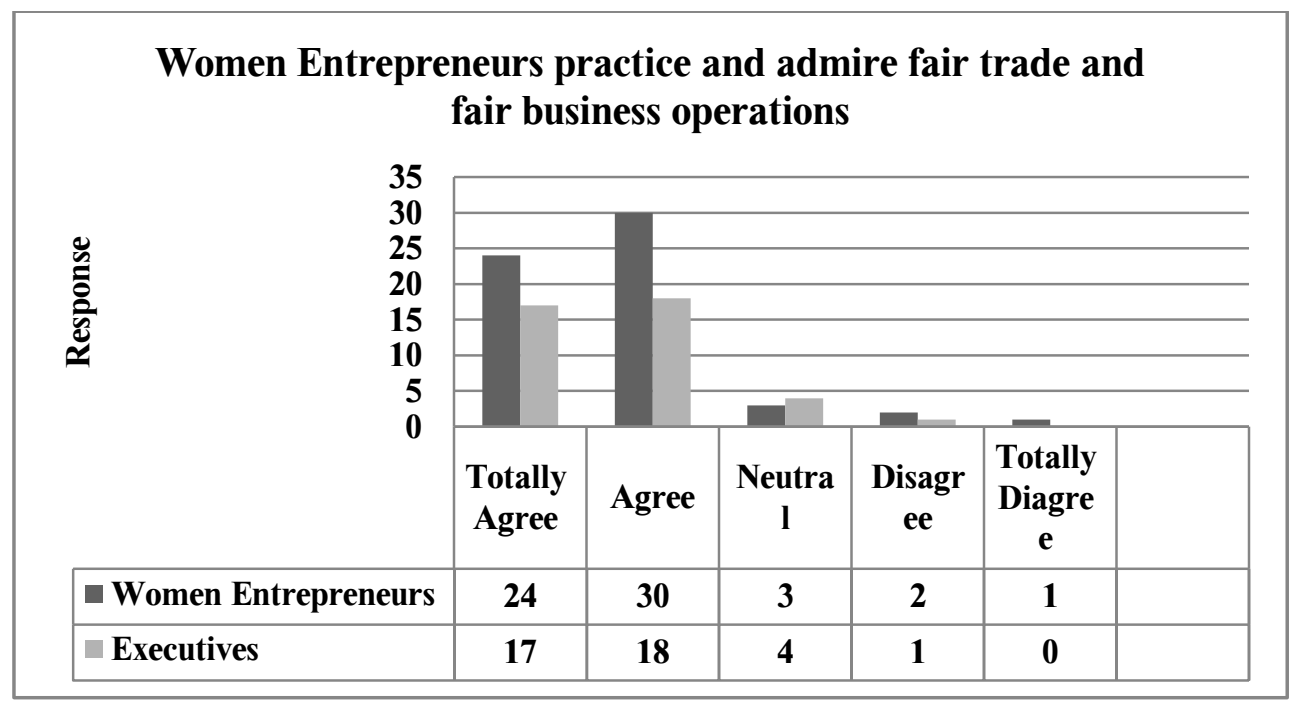

Source: Survey data

According to the women entrepreneurs who participated in the interview mentioned that they are engaged in fair trade and fair business activities. The Figure 18 shows that is accepted by majority of executives and women entrepreneurs who participated in this survey. Particularly mentioned practices are creating opportunities for poor producers, fair trading practices; receipts and payments, ensuring no discrimination and maintaining safe working conditions.

\section{Conclusion}

In recent decades, there is an increasing interest in women entrepreneurship development. Governments, policy makers and academics paid a special attention on developing this area particularly 
in developing countries. This interest has made countries to establish and support women entrepreneurship, especially in rural areas. This resulted to bring local capabilities to the rural economic growth and take them into the self-employment. Most importantly, this concept helped government to eliminate the poverty and create employment opportunities. Women as entrepreneurs are now playing a far role than the introductory stage. They are more educated and well aware of the information. Now they received another challenge to drive the economy to sustainable development. Socially responsible, economically concerned and environment friendly activities in these enterprises reach their own business goals. These businesses focus trading with poor, helping the community to develop skills and abilities, paying fair prices and receiving fair payments, encouraging fair treatment of all staff and encouraging environment-friendly conditions in business operations. These activities are significant in sustainable development of a country. Developing nations must pay their attention further to the women entrepreneurs. The governments of developing nations must be considered how to build Women capacity in business development, including their capability to become productive and innovative entrepreneurs and taking their contribution to the national economy. 


\section{References}

Birley, S., Harris, P., \& Harris. P. (1988). Female Enterprenurs - are they really any different :Journal of Small Business Management Cranfield School of Management Cranfield Institute of Technology Cranfield Bedford MK43 OAL United Kingdom.

Brush, C. G. (1992). Research on Women Business Owners: Past Trends, A New Perspective \& Future Direction. Entrepreneurship Theory and Practice.vol 16, 5-30.

Elliot, J. A. (2006). An Introduction to Sustainable Development, $3^{\text {rd }}$ Edition, Routledge Perspective on Development Series, Abingdon, Oxon.

Frederick, H. H., \& Kuratko, H. F. (2010). Entrepreneurship, theory, process and practice, Sengage Australia (Pvt) Limited.

Forbes, (2012). Entrepreneurship Is The New Women's Movement [Online] Available from: http://www.forbes.com/sites/work-inprogress/2012/06/08/entrepreneurship-is-the-new-womensmovement [Accessed: 11th August 2013].

Henry, C. Hill, (2003). Entrepreneurship education and training, Aldershot, Ashagate publishing Ltd.

Mehta, S., \& Sethi, N. (1997). "Targeting women for Development”, ” Social Welfare journal, Vol.34, No.10.

UNIDO, (2001). Women entrepreneurship development in selected African countries, Working Paper No. 7, [Online] Available at: http://www.unido.org/fileadmin/user_media/Publications/Pub_ free/Women_entrepreneurship_development_in_selected_Afri can_countries.pdf [accessed 13/03/2011]. 
United Nations Foundation, (2014). Resolutions: Female Entrepreneurs Are Key to Sustainable Global Development, [Online] Available from:

http://www.unfoundation.org/blog/femaleentrepreneurs.html[Accessed: $08^{\text {th }}$ November 2014]

United Nations World Commission on Environment and

Development,(1987). Our Common Future, Chapter 2:

Towards Sustainable Development ,[online] Available from http://www.un-documents.net/ocf-02.htm [accessed 07/05/2014]

World Economic Forum, (2014). The Global Gender Gap

Report,[online] http://www3.weforum.org/docs/GGGR14/GGGR_CompleteRe port_2014.pdf [accessed 13/04/2013]

Zororo, M. (2011). Characteristics and Motivation in Female Entrepreneurship. Case of Botswana. University of Botswana Journal. 